\title{
Editorial \\ Land as a Basis for Recent Progress in the Study of Urbanization Dynamics
}

\author{
Iwona Cieślak $^{1, *(\mathbb{D})}$, Andrzej Biłozor $\left.{ }^{1} \mathbb{(}\right)$ and Luca Salvati ${ }^{2}$ \\ 1 Department of Socio-Economic Geography, Faculty of Geoengineering, University of Warmia and Mazury in \\ Olsztyn, Prawocheńskiego 15, 10-720 Olsztyn, Poland; abilozor@uwm.edu.pl \\ 2 Department of Economics and Law, University of Macerata, Via Armaroli 43, 62100 Macerata, Italy; \\ luca.salvati@crea.gov.it \\ * Correspondence: isidor@uwm.edu.pl
}

check for

updates

Citation: Cieślak, I.; Biłozor, A.;

Salvati, L. Land as a Basis for Recent Progress in the Study of Urbanization Dynamics. Land 2022, 11, 118. https://doi.org/10.3390/land11010118

Received: 4 January 2022

Accepted: 10 January 2022

Published: 12 January 2022

Publisher's Note: MDPI stays neutral with regard to jurisdictional claims in published maps and institutional affiliations.

Copyright: (C) 2022 by the authors. Licensee MDPI, Basel, Switzerland. This article is an open access article distributed under the terms and conditions of the Creative Commons Attribution (CC BY) license (https:// creativecommons.org/licenses/by/ $4.0 /)$.
Urbanization is one of the most dynamic processes occurring on the Earth. The urban population continues to increase due to the benefits of the urban lifestyle and the economic and social aspects of urbanization. This process became especially intensified in the second half of the 20th century, when the number of urban dwellers rose from 751 million to 4.2 billion in 2018. According to international forecasts, by 2050, the world's urban population will grow by another 2.5 billion, i.e., by $68 \%$. However, the rapid rate of urbanization leads to serious environmental, spatial and socio-economic problems such as soil degradation, loss of urban ecosystem services, urban heat islands and air pollution. Health problems, urban poverty, rising crime and overcrowding are also becoming very acute. However, it should be noted that urbanization is perceived positively in many dimensions. Planned and sustainable urban development is the basis of a properly functioning economy, promoting a rise in living standards through higher quality of education and improved access to healthcare, culture and art. Researchers thus devote much attention to this process and monitor it constantly. Until recently, statistical data, including population or investment growth in administrative units, were the primary source of information for studying urbanization processes in the global or local dimension. This process could not be followed with a frequency suited to the rate of its progress based on data on spatial transformation. However, enormous databases containing a broad spectrum of spatial information, as well as new and rapid tools for processing spatial data have been available to researchers for more than 20 years, not only locally, but also on the international and global scale. The scope and quality of research on urbanization processes based on land data are also increasing. According to estimates, in 1990-2000, the average annual increase in built-up land was approximately $3.6 \%$ in developing countries and only $2.9 \%$ in industrialized countries. The most dynamic changes in land use towards urbanization have been observed in East Asia, including the Pacific region, and South-East Asia, where the increase in urbanized land reached $7.2 \%$ and $6.4 \%$, respectively. In Europe, the annual increase in urban area does not exceed $2 \%$ in the most rapidly developing areas and is close to zero in rural areas.

Land use (LU) studies have become easier thanks to land cover (LC) observations. Land cover analyses are becoming increasingly advanced and provide knowledge on all dimensions of urbanization at various scales of reference. Most of the world's urban areas have experienced significant changes in land cover over the years. Land data, generally referred to as Spatial Information System (SIS) data, are increasingly used in research. The SIS provides information on LU/LC and currently covers various areas of interest, including administrative boundaries, transport and hydrographic networks, terrain, settlement and anthropogenic structures. These data are expanded to include environmental and social dimensions that describe not only the changes taking place in the environment, but also in the quality of life. SIS databases are being created at all levels of detail. Various types of national spatial information systems provide access to key data. In this case, spatial data 
refer to location (coordinates in the adopted reference system), the geometric properties and spatial relationships of objects that are identified in relation to the Earth and can be used in the analyses of urbanization processes. Spatial information can be presented cartographically and analyzed to identify urbanization patterns. Based on this reasoning, the Earth is one of the primary sources of information on urbanization processes.

Urbanization causes deep changes in space and gradually modifies the land use structure. There is an enormous need for monitoring urban space as well as changes that occur in areas directly subjected to urbanization pressure. The development of science and technology has provided many new tools for the observation of urbanization processes and the formulation of conclusions about this phenomenon. Recent Progress in Urbanization Dynamics Research contains a broad range of papers presenting the complexity of the urbanization process, and varied approaches focusing on different aspects of urban development in relation to land development emphasize the need for further research on urbanization. Different chapters are dedicated to the dynamics of urbanization processes, rapid changes in urbanization and scattered development of urban areas, zoning, sustainable development, urban sprawl, spatial conflicts, the real estate market, transport accessibility, spatial analyses involving GIS tools and map-making methods. Specifically, the authors focus on:

- The latest research results and the most interesting methods and information sources used in studies of urbanization dynamics. Numerous examples and potential uses of spatial data for the analyses of urbanization processes are also presented [1].

- A geospatial analysis of urban development patterns aiming to identify the characteristic features of urban expansion with the use of the Geographic Information System (GIS) and remote detection techniques (Landsat images) [2].

- Monitoring and modeling urban development patterns and trends with the use of the Urban Sprawl Matrix and CA-Markov Model, analyzing changes in the urban landscape and predicting LULC changes [3].

- Spatial and temporal characterization of urban expansion with the use of a concentricring and grid-based analysis. These approaches were combined to describe urban expansion processes in five large Latin American cities in 2000-2014 [4].

- An analysis of temporal and spatial patterns and urban expansion factors in the Texas Triangle Megaregion with the use of land cover data and the imperviousness of the National Land Cover Database transport data for 2001-2016, transport data from the Texas Department of Transportation (TxDOT) and auxiliary socio-demographic data [5].

- Urban Innovation Efficiency Improvement in the Guangdong-Hong Kong-Macao Greater Bay Area from the Perspective of Innovation Chains, presenting a three-step "knowledge innovation-scientific research innovation-product innovation" model that proposes effective solutions and suggestions regarding the promotion and optimization of innovations based on cooperation in the Greater Bay Area, in view of various factors, industrial structure and urban agglomeration innovation networks [6].

- Analysis of susceptibility to land-use conflict aimed at developing a procedure for evaluating the risk of conflict in land management based on the specific attributes of land with the use of databases, GIS tools and statistical data-processing methods [7].

- Analysis and evaluation of the spatial structure of Cittaslow cities based on examples of several regions in central Italy and north-eastern Poland, including an assessment of the urban layout, architectural features and the composition of urban and architectural factors that are largely responsible for the perception of multidimensional spaces [8].

- Spatial differences in land-use change indicators per capita in Rome in central Italy (in 1949, 1974, 1999, 2008 and 2016) with the aim of quantifying the discrepancies between urban expansion and population growth. The empirical results of this study encourage a discussion on the (presumed) unsustainability of the current urban expansion compared to former settlement structures, which can be attributed to land fragmentation, loss of relict habitats and traditional croplands on the outskirts of the city [9]. 
- Spatial processes accompanying the loss and expansion of forests in the Rome metropolitan area with the use of diachronic maps from 1936-2018, representing different socioeconomic conditions [10].

- Promoting the high-quality development of areas subjected to urbanization pressure, improving the effectiveness of green innovations in urban agglomerations, analyzing the impact of network structure characteristics (such as network scale and network structure hole) on green innovations in urban agglomerations with the use of the unexpected output SBM model to measure green innovation efficiency in eight prefecturelevel cities in the Great Changsha-Zhuzhou-Xiangtan City Group, and to analyze the contributing factors using the panel Tobit model [11].

- Improved methodology for selecting the optimum solutions for sustainable spatial and traffic planning by combining quantifiable results of traffic microsimulation with the multi-criteria optimization method [12].

- Transport accessibility in the suburban zone and its impact on the local real estate market, in view of commuting time and demographic changes. The spatial differentiation in population distribution was analyzed with the use of the Gini index and geostatistical interpolation techniques [13].

- The role and significance of a pedestrian freeway overpass in Trabzon. Safety issues and the motivation for using the overpass among respondents from different age groups were described in detail [14].

All of the discussed topics relate to urbanization processes that are observed on a daily basis as well as the methods and techniques for monitoring these phenomena. The relationship between urbanization and space seems obvious, but it is also interesting and multi-layered. Scientific and technological advancement has generated numerous tools for observing urbanization processes, conducting analyses and formulating conclusions about urbanization. Recent Progress in Urbanization Dynamics Research presents the latest research trends by relying on the extensive body of knowledge relating to urban geography. Special emphasis was placed on the global effects of urbanization, and this multidisciplinary phenomenon was analyzed with the use of satellite and photogrammetric observation techniques and GIS tools.

Author Contributions: Conceptualization, I.C. and A.B.; writing-original draft preparation, I.C. and A.B.; writing - review and editing, I.C., A.B. and L.S. All authors have read and agreed to the published version of the manuscript.

Acknowledgments: We thank all the reviewers for their feedback on earlier versions of the manuscripts in this Special Issue.

Conflicts of Interest: The authors declare no conflict of interest.

\section{References}

1. Biłozor, A.; Cieślak, I. Review of Experience in Recent Studies on the Dynamics of Land Urbanisation. Land 2021, $10,1117$. [CrossRef]

2. Seevarethnam, M.; Rusli, N.; Ling, G.H.T.; Said, I. A Geo-Spatial Analysis for Characterising Urban Sprawl Patterns in the Batticaloa Municipal Council, Sri Lanka. Land 2021, 10, 636. [CrossRef]

3. Baqa, M.F.; Chen, F.; Lu, L.; Qureshi, S.; Tariq, A.; Wang, S.; Jing, L.; Hamza, S.; Li, Q. Monitoring and Modeling the Patterns and Trends of Urban Growth Using Urban Sprawl Matrix and CA-Markov Model: A Case Study of Karachi, Pakistan. Land 2021, 10, 700. [CrossRef]

4. Wu, S.; Sumari, N.S.; Dong, T.; Xu, G.; Liu, Y. Characterizing Urban Expansion Combining Concentric-Ring and Grid-Based Analysis for Latin American Cities. Land 2021, 10, 444. [CrossRef]

5. Guo, J.; Zhang, M. Exploring the Patterns and Drivers of Urban Expansion in the Texas Triangle Megaregion. Land 2021, 10, 1244. [CrossRef]

6. Ye, W.; Hu, Y.; Chen, L. Urban Innovation Efficiency Improvement in the Guangdong-Hong Kong-Macao Greater Bay Area from the Perspective of Innovation Chains. Land 2021, 10, 1164. [CrossRef]

7. Cieślak, I.; Biłozor, A. An Analysis of an Area's Vulnerability to the Emergence of Land-Use Conflicts. Land 2021, 10, 1173. [CrossRef] 
8. Zagroba, M.; Pawlewicz, K.; Senetra, A. Analysis and Evaluation of the Spatial Structure of Cittaslow Towns on the Example of Selected Regions in Central Italy and North-Eastern Poland. Land 2021, 10, 780. [CrossRef]

9. Bianchini, L.; Egidi, G.; Alhuseen, A.; Sateriano, A.; Cividino, S.; Clemente, M.; Imbrenda, V. Toward a Dualistic Growth? Population Increase and Land-Use Change in Rome, Italy. Land 2021, 10, 749. [CrossRef]

10. Bianchini, L.; Salvia, R.; Quaranta, G.; Egidi, G.; Salvati, L.; Marucci, A. Forest Transition and Metropolitan Transformations in Developed Countries: Interpreting Apparent and Latent Dynamics with Local Regression Models. Land 2022, 11, 12. [CrossRef]

11. Wang, L.; Ye, W.; Chen, L. Research on Green Innovation of the Great Changsha-Zhuzhou-Xiangtan City Group Based on Network. Land 2021, 10, 1198. [CrossRef]

12. Ištoka Otković, I.; Karleuša, B.; Deluka-Tibljaš, A.; Šurdonja, S.; Marušić, M. Combining Traffic Microsimulation Modeling and Multi-Criteria Analysis for Sustainable Spatial-Traffic Planning. Land 2021, 10, 666. [CrossRef]

13. Szczepańska, A. Transport Accessibility in a Suburban Zone and Its Influence on the Local Real Estate Market: A Case Study of the Olsztyn Functional Urban Area (Poland). Land 2021, 10, 465. [CrossRef]

14. Hełdak, M.; Kurt Konakoglu, S.S.; Kurdoglu, B.C.; Goksal, H.; Przybyła, B.; Kazak, J.K. The Role and Importance of a Footbridge Suspended over a Highway in the Opinion of Its Users-Trabzon (Turkey). Land 2021, 10, 340. [CrossRef] 